\title{
Incidence of aflatoxin M1 contamination in milk, white cheese, kashar and butter from Sakarya, Turkey
}

\author{
Suzan ÖZTÜRK YILMAZ ${ }^{1 *}$, Alev ALTINCI²
}

\begin{abstract}
The purpose of this research is to determine the incidence and occurrence of aflatoxin M1 (AFM1) in 104 samples of milk, white cheese, kashar and butter in Sakarya, Turkey. Followed by immunoaffinity column (IAC) purification, high performance liquid chromatography (HPLC)-fluorescence detection method was implemented to analyze the samples. Results show that $61.5 \%$ of milk, $40 \%$ of white cheese, $65.4 \%$ of kashar and $29.6 \%$ of butter contains AFM1. In 53 of samples $(50.96 \%)$ are not determined AFM1. The amount of AFM1 in 51 samples (49.04\%) ranges from 2.4 to $47.8 \mathrm{ng} / \mathrm{L} / \mathrm{kg}$. AFM1 levels do not exceed the limit set by Turkish regulations $(50 \mathrm{ng} / \mathrm{L} / \mathrm{kg})$. However, the incidence of AFM1 contamination is a potential health risk for customers, particularly for children and infants. These results emphasize the significance of constant monitoring of AFM1 levels in milk and dairy products (MDPs) in Sakarya, Turkey.
\end{abstract}

Keywords: aflatoxin M1, milk, white cheese, kashar, HPLC, fluorescence detection.

Practical Application: Monitoring of aflatoxin M1 levels in milk and dairy products.

\section{Introduction}

Considered a milk toxin, aflatoxin M1 (AFM1) is the main hydroxylated metabolite of aflatoxin B1 (AFB1) in liver due to cytochrome enzymes and detected in milk and dairy products (MDPs) (Fallah et al., 2009). Mycotoxin contamination in dairy cow nutrition is mainly caused by corn and silage (Bilandžić et al., 2016). Studies indicate that when a dairy cow consumes approximately $40 \mu \mathrm{g} / \mathrm{kg}$ of AFB1 daily, the milk it produces contains $0.05 \mu \mathrm{g} / \mathrm{kg}$ (highest level) of AFM1 (Joint FAO/WHO Expert Committee on Food Additives, 2002). Varying according to AFB1 contamination level in feeds, around 0.3 to $6.2 \%$ of AFB1 consumed by dairy animals is chemically modified into AFM1 (Ayar et al., 2007).

The incidence of AFM1 in MDPs poses a potential health risk for animals and humans in general and for susceptible population groups such as infants and young children in particular (Piva et al., 1988). Health risks posed by AFM1 consumption are liver diseases, reduction in dairy farming, the dampening of the immune response and hemoglobin deficiency. AFM1 also causes dairy animals to consume less feed and hinders their development (Beasley, 2011). Despite the fact that AFM1 has lower genotoxic activity than AFB1, the latter is considered by the International Agency for Research on Cancer (IARC) to be carcinogenic to humans (Group 2B). Due to the toxicity and carcinogenicity of AFM1, IARC reevaluated the carcinogenic category and upgraded AFM1 from Group 2B (possibly carcinogenic to humans) to Group 1 (carcinogenic to humans) (International Agency for Research on Cancer, 2012). Pasteurization and sterilization are not able to deactivate AFM1 (Prandini et al., 2009). The fact that AFM1 can only be inactivated at temperatures above $250{ }^{\circ} \mathrm{C}$ (Ellis et al., 1991) forced authorities to lay down limits and regulations for total AFM1 content in MDPs to minimize health risks. The limit laid down by the Turkish Food Codex is $50 \mathrm{ng} / \mathrm{kg}$ AFM1 in MDPs (Turkish Food Codex, 2011). Contamination levels and distribution variations of AFM1 vary according to season and location (Aliabadi et al., 2012).

The temperature of the western Black Sea Region in the North of Turkey ranges from $-8{ }^{\circ} \mathrm{C}$ to $40{ }^{\circ} \mathrm{C}$ with an average humidity of $72 \%$ and it is often cloudy (Bakirdere et al., 2014).

The climatic conditions of the region, and therefore of Sakarya, are suitable for the incidence of mycotoxigenic molds such as A. flavus and A. parasiticus in foodstuffs (Gul \& Dervisoglu, 2014). There are numerous studies about the incidence of AFM1 in MDPs in Turkey (Aksoy et al., 2010; Ardic et al., 2009; Ayçiçek et al., 2005; Bakırdere et al., 2014; Colak et al., 2006; Ertaş et al., 2011; Golge 2014; Gurbay et al., 2006; Oruç, 2003; Tosun \& Ayyildiz, 2013). However, the number of studies on the incidence of AFM1 in milk, kashar, white cheese and butter in Sakarya is limited. The purpose of this research is to assess the health and safety issues concerning milk and dairy product consumption and to emphasize the significance of constant monitoring of potential AFM1 contamination in MDPs for the protection of consumer health.

\section{Materials and methods}

\subsection{Sampling}

Study sample consists of 26 MDPs, 25 white cheeses, 26 kashars and 27 butters (each about $500 \mathrm{~g}$ or $\mathrm{mL}$ ). They were purchased from various retail shops, bazaars, supermarkets 
and local markets in the city of Sakarya, Turkey, between 2014 and 2015, and transferred to a lab in an insulated container at around $4{ }^{\circ} \mathrm{C}$ to be analyzed.

\subsection{Chemicals}

Fluxing agents (HPLC-grade) used for the tests were supplied from Merck (Darmstadt, Germany) and Sigma (St. Louis, USA). Afla M1 immunoaffinity columns were supplied from VICAM (Watertown, MA, USA) and aflatoxin M1 standard was supplied from Supelco (Sincer, Turkey). Standard stock solutions of aflatoxin $\mathrm{M} 1$ was kept at $-20^{\circ} \mathrm{C}$.

\subsection{Aflatoxin M1 analysis in samples by HPLC}

A hundered milliliters milk was heated up to $37^{\circ} \mathrm{C}$ and gently stirred to better dissolve the fat. The upper thin fat layer of the milk samples centrifuged at $2000 \mathrm{rpm}$ for $10 \mathrm{~min}$ was, then, discarded. Whatman No.4 paper (Brendford, UK) was used to filter the bottom skimmed milk layer and analyses were conducted on a 50-mL filtrate (Iqbal \& Asi, 2013).

Cheese and butter samples were prepared as described by Mayes \& McDonald (1995), and Iqbal \& Asi (2013). $40 \mathrm{~g}$ cheese, $10 \mathrm{~g}$ Celite-545, $150 \mathrm{~mL}$ chloroform, and $2 \mathrm{~mL}$ saturated sodium chloride solution was stirred using an Ultra Turrax blender ( $\mathrm{GmbH}$, Germany) at a speed of $2.5 \mathrm{~min}$ to allow formation of a uniform slurry, which was filtered using Whatman No. 4 filter paper. The filtrate was dried under vacuum at $60{ }^{\circ} \mathrm{C} .2 \mathrm{~mL}$ methanol, $100 \mathrm{~L}$ phosphate-buffered saline and $70 \mathrm{~mL}$ hexane were introduced into the mixture, which was put into a separatory funnel $(500 \mathrm{~mL})$. Hexane $(100 \mathrm{~mL})$ was placed into the separatory funnel. The mixture was firmly shaken to remove the aqueous sample. A section of the bottom layer $(50 \mathrm{~mL})$ was collected for analysis. An immunoaffinity column (Vicam Afla M1, Watertown, Mass.) was used to filter an aliquot $(50 \mathrm{~mL})$ of the filtrate from each sample. The antibodies attached to AFM1 formed an antibody-antigen complex, which was washed off with $20 \mathrm{~mL}$ water off the column. The toxin was eluted using $4 \mathrm{~mL}$ acetonitrile. The final extract was evaporated to $300 \mu \mathrm{l}$ under the nitrogen stream and finally redissolved in the HPLC mobile phase to $3 \mathrm{~mL}$.

The volume of injection into HPLC was $100 \mu \mathrm{L}$. The mobile phase was composed of acetonitrile-water (25:75, vol/vol) delivered to the column at a rate of $1 \mathrm{~mL} / \mathrm{min}$ (Deveci, 2007). The mobile phase was filtered through a disposable filter unit $(0.45 \mu \mathrm{m})$. An HPLC system was employed to determine AFM1. The HPLC system detected AFM1 presence using a fluorescence detector (RF 20A) at $365 \mathrm{~nm}$ (excitation wave-length) and $435 \mathrm{~nm}$ (emission wave-length). The peaks were compared with the actual sample peaks.

\section{Results}

HPLC analysis results show that the recovery rate of the analyte in spiked samples ranges from 83.20 to $104.01 \%$ and a relative standard deviation (RSD) varying between 0.51 and $2.40 \%$. Recoveries of AFM1 from milk, white cheese, kashar and butter are $83.20,90.41,90.60$ and $104.01 \%$, respectively (Table 1).
The recovery rates are consistent with the recommended recovery (70-110\%) of mycotoxins in foods Commission Regulation (European Union, 2006). Table 1 shows that the limit of detection (LOD) and the limit of quantification (LOQ) of the method range from 1.03 to 1.20 and from 3.00 to $3.02 \mathrm{ng} / \mathrm{L} / \mathrm{kg}$, respectively.

Table 2 summarizes the results of samples for AFM1. AFM1 levels in milk, white cheese, kashar and butter are $61.54 \%$ (16/26), 40.00\% (10/25), 65.38\% (17/26) and 29.63\% (8/27), respectively. The positive mean values of AFM1 in milk, white cheese, kashar and butter are $38.22 \mathrm{ng} / \mathrm{L}, 17.14 \mathrm{ng} / \mathrm{kg}, 25.50 \mathrm{ng} / \mathrm{kg}$ and $15.71 \mathrm{ng} / \mathrm{kg}$, respectively. The total occurrence and positive mean of AFM1 are 49.04\% (51/104) and $24.14 \mathrm{ng} / \mathrm{kg}$, respectively.

Table 3 demonstrates the minimum-maximum AFM1 levels and lower or upper AFM1 limits of the samples. The results clearly show that $10(38.46 \%)$ milk, $15(60.00 \%)$ white cheese, $9(34.62 \%)$

Table 1. Recovery, Limit of detection and limit of quantification for AFM1 in milk, cheese and butter samples.

\begin{tabular}{cccc}
\hline $\begin{array}{c}\text { Milk and dairy } \\
\text { products sample }\end{array}$ & $\begin{array}{c}\text { Mean recovery } \\
(\mathrm{N}) \pm \mathrm{RSD}^{\mathrm{b}}(\%)\end{array}$ & LOD $(\mathrm{ng} / \mathrm{L} / \mathrm{kg})$ & $\mathrm{LOQ}(\mathrm{ng} / \mathrm{L} / \mathrm{kg})$ \\
\hline Milk & $83.20 \pm 2.40$ & 1.03 & 3.14 \\
White Cheese & $90.41 \pm 0.51$ & 1.08 & 3.01 \\
Kashar & $90.60 \pm 1.22$ & 1.02 & 3.00 \\
Butter & $104.01 \pm 1.90$ & 1.10 & 3.02 \\
\hline
\end{tabular}

Table 2. Occurrence and level of AFM1 in milk and dairy products (n:104).

\begin{tabular}{|c|c|c|c|}
\hline $\begin{array}{l}\text { Milk and } \\
\text { dairy } \\
\text { products } \\
\text { sample }\end{array}$ & $\begin{array}{c}\text { Number of } \\
\text { positive samples/ } \\
\text { Number of total } \\
\text { samples (n) }\end{array}$ & $\begin{array}{c}\text { Percentage of } \\
\text { positive samples } \\
\text { (\%) }\end{array}$ & $\begin{array}{c}\text { Level of AFM1 } \\
(\mathrm{ng} / \mathrm{L})^{\mathrm{a}} /(\mathrm{ng} / \mathrm{kg})^{\mathrm{b}} \\
\text { Positive mean } \\
\quad \pm \text { RSD }\end{array}$ \\
\hline Milk & $16 / 26$ & 61.54 & $38.22 \pm 1.25$ \\
\hline $\begin{array}{l}\text { White } \\
\text { Cheese }\end{array}$ & $10 / 25$ & 40.00 & $17.14 \pm 4.20$ \\
\hline Kashar & $17 / 26$ & 65.38 & $25.50 \pm 7.23$ \\
\hline Butter & $8 / 27$ & 29.63 & $15.71 \pm 3.80$ \\
\hline Total & $51 / 104$ & 49.04 & $24.14 \pm 4.11$ \\
\hline
\end{tabular}

Table 3. Min.-max. levels of AFM1 and number of milk and dairy products exceeding the Turkish Food Codex (TFC) (n: 104).

\begin{tabular}{|c|c|c|c|c|}
\hline $\begin{array}{l}\text { Milk and } \\
\text { dairy } \\
\text { products } \\
\text { sample }\end{array}$ & $\begin{array}{l}\text { Number } \\
\text { of total } \\
\text { sample }\end{array}$ & $\begin{array}{c}\text { Min.-Max. } \\
\text { levels } \\
\text { (ng/L or ng/kg) }\end{array}$ & $\begin{array}{c}\text { Below TFC } \\
\text { limit } \\
\left(<50^{\mathrm{a}} \mathrm{ng} / \mathrm{L} / \mathrm{kg}\right)\end{array}$ & $\begin{array}{c}\text { Number } \\
\text { of samples } \\
\text { exceed TFC } \\
\text { limit } \\
\text { (>50 ng/L/kg) }\end{array}$ \\
\hline Milk & 26 & $3.00-47.81$ & $10(38.46 \%)$ & $-*$ \\
\hline $\begin{array}{l}\text { White } \\
\text { Cheese }\end{array}$ & 25 & $2.46-35.00$ & $15(60.00 \%)$ & - \\
\hline Kashar & 26 & $6.08-45.43$ & $9(34.62 \%)$ & - \\
\hline Butter & 27 & $5.20-48.22$ & $19(70.37 \%)$ & - \\
\hline Total & 104 & $2.46-48.22$ & $53(50.96 \%)$ & - \\
\hline
\end{tabular}


kashar and 19 (70.37\%) butter samples are not contaminated with AFM1. The minimum-maximum levels of milk, white cheese, kashar and butter are 3.00-47.81 ng/L, $2.46-35.00 \mathrm{ng} / \mathrm{kg}$, $6.08-45.43 \mathrm{ng} / \mathrm{kg}$ and $5.20-48.22 \mathrm{ng} / \mathrm{kg}$, respectively. None of the AFM1 levels of the samples exceed the TFC limits (Turkish Food Codex, 2011).

\section{Discussion}

Numerous researchers from different countries have indicated that AFM1 causes various health risk when people consume MDPs (Li et al., 2017; Ketney et al., 2017). Mean AFM1 levels in raw milk samples from Bosnia and Herzegovina and Croatia are $6.22 \mathrm{ng} / \mathrm{kg}$ and $5.65 \mathrm{ng} / \mathrm{kg}$, respectively. Bilandžić et al. (2016) detected concentrations of AFM1 in four milk samples ranging from 53.7 to $123.8 \mathrm{ng} / \mathrm{kg}$, thus, exceeding the European Union (2010) limit of $50 \mathrm{ng} / \mathrm{kg}$. Li et al. (2017) point out that AFM1 levels in 2014 and 2015 range from 5 to $263 \mathrm{ng} / \mathrm{L}$ and from 5 to $65 \mathrm{ng} / \mathrm{L}$, respectively (Mean: $41 \mathrm{ng} / \mathrm{L}$ ). Fallah (2010) states that toxin level in $66(72.5 \%)$ pasteurized milk samples ranges from 13.0 to $250.0 \mathrm{ng} / \mathrm{L}$ (Mean: $52.0 \mathrm{ng} / \mathrm{L}$ ). Oliveira et al (2013) report AFM1 contamination ranging from 1000 to $4100 \mathrm{ng} / \mathrm{L}$ in 21 (30.7\%) out of 75 UHT liquid milk samples in Brazil. Similarly, Yoon et al. (2016) report AFM1 in 108 milk samples ranging from 1 to $100 \mathrm{ng} / \mathrm{L}$ in South Korea. Above studies report higher rates of AFM1 contamination in milk than those found in this study (3.0-47.8 ng/L). Mean levels of AFM1 contamination in 84/153 UHT and 25/26 pasteurized milk samples in China are $48 \mathrm{ng} / \mathrm{L}$ and $72 \mathrm{ng} / \mathrm{L}$, respectively (Zheng et al., 2013). A recent study from Malaysia also reports AFM1 contamination (Mean: $93.0 \mathrm{ng} / \mathrm{L}$ ) in $33.3 \%$ of milk samples (Farah Nadira et al., 2017). In this study, AFM1 contamination rate in milk samples (49.04\%) is lower than those reported by most studies, except for Oliveira et al. (2013), and Farah Nadira et al. (2017). Rama et al. (2016) state that AFM1 levels in 5.4\% (895) milk samples range from 52.2 to $26.6 \mathrm{ng} / \mathrm{L}$ in 2009 and from 6.3 to $9.81 \mathrm{ng} / \mathrm{L}$ in 2010 . In the study conducted by Abdolgader et al. (2017), 36 out of 42 sterilized milk samples contain AFM1 (the highest level: $160.0 \mathrm{ng} / \mathrm{L}$; Mean: $29.0 \mathrm{ng} / \mathrm{L}$ ). AFM1 contamination level of none of the samples in this study exceeds the limit set by the TFC (Turkish Food Codex, 2011) and those reported by the aforementioned studies (Table 3). Some studies on pasteurized and UHT milk in Turkey report AFM1 levels exceeding the limit laid down by the EC (Bilandžić et al., 2016). Tekinsen \& Eken (2008) report the presence of AFM1 in 67\% of the 100 UHT milk samples. In another study they conducted, AFM1 levels in 61 milk samples range from 5.0 to $410 \mathrm{ng} / \mathrm{L}$. In the study carried out by Bakırdere et al. (2014), 61 samples (79.22\%) contain AFM1 with a mean of $31.0 \mathrm{ng} / \mathrm{L}$, however, AFM1 levels of only 4 of them exceed the limit of $50 \mathrm{ng} / \mathrm{L}$. In a study conducted by Golge (2014) in Adana, Turkey, AFM1 residue levels in 31.8\% of milk samples range from 42 to $552 \mathrm{ng} / \mathrm{kg}$, which is higher than those found in this study.

AFM1 levels in cheese samples were expected to be high as there are many studies reporting a higher occurrence of AFM1 contamination in cheese. Ardic et al. (2009) report AFM1 contamination in 158 of 192 white cheese samples. AFM1 contamination levels of 51 of the samples exceed $250 \mathrm{ng} / \mathrm{kg}$.
Bakırdere et al. (2014) find AFM1 contamination in 36 of 67 white cheese samples, the levels of which vary between 50 and $2100 \mathrm{ng} / \mathrm{kg}$, with a mean of $280.0 \mathrm{ng} / \mathrm{kg}$. Yoon et al. (2016) report an incidence of AFM1 contamination in 61 cheese samples ranging from 15 to $150 \mathrm{ng} / \mathrm{kg}$ (Mean: $37 \mathrm{ng} / \mathrm{kg}$ ). In a recent study conducted by Sharifzadeh et al. (2017), 52 of the samples are reported to be contaminated by AFM1, the levels of which range from 50.2 to $424.4 \mathrm{ng} / \mathrm{kg}$. AFM1 levels of 8 of the samples vary between 250.2 and $424.4 \mathrm{ng} / \mathrm{kg}$. AFM1 levels of $25(65.5 \%)$ of total cheese samples are reported to range from 52.2 to $272 \mathrm{ng} / \mathrm{kg}$, with a mean of $158.4 \mathrm{ng} / \mathrm{kg}$ by Bahrami et al. (2016). In Fallah's study (2010), toxicity levels of 59 (81.9\%) of white cheese samples vary between 30 and $1200 \mathrm{ng} / \mathrm{kg}$ (Mean: $297 \mathrm{ng} / \mathrm{kg}$ ). Gurses et al. (2004) analyzes 77 cheese samples and reports an incidence of AFM1 in about $44 \%$ of samples, however, none of AFM1 levels exceeds the legal limit of the TFC. In another study, AFM1 levels of cheese samples range from 16 to $136 \mathrm{ng} / \mathrm{kg}$ (Koluaçık et al., 2015). In a study carried out by Aksoy et al. (2010), 25 fresh white cheese samples were randomly collected from Samsun, Turkey. The incidence of AFM1 contamination in the samples is $12 \%$. AFM1 levels of the samples do not exceed the limit set by the TFC. These results are consistent with those of this study reporting that AFM1 levels of $40.0 \%$ of the samples range from 2.46 to $35.00 \mathrm{ng} / \mathrm{kg}$. AFM1 levels vary according to various elements such as region, season, cheese-making procedures, analytical method and conditions of cheese ripening (Fallah et al., 2009; Ketney et al., 2017).

Being one of the most popular cheeses, Kashar is a semi-hard and traditional cheese commercially produced in Turkey (Ozdemir \& Demirci, 2006). There are various studies conducted on kashar. Gul \& Dervisoglu (2014) detect AFM1 in 144 of 147 cheese samples, the levels of which range from 15 to $3774 \mathrm{ng} / \mathrm{kg}$ with a mean of $273 \mathrm{ng} / \mathrm{kg}$. AFM1 levels in 16 (11.11\%) of the samples exceed the maximum acceptable limits (500 ng/kg). In the study conducted by Tekinsen \& Eken (2008) on kashar, 82.6\% of 132 samples are contaminated with AFM1. Aksoy et al. (2010) report an incidence of AFM 1 contamination in the $80 \%$ of fresh kashar samples. These rates are higher than those found in this study. However, AFM1 levels in 36 (27.3\%) kashar samples in the studies stated above exceed the maximum tolerable limit set by the TFC. Cetin (2004) examines the incidence of Aflatoxin M1 in 25 kashar samples purchased from markets in Ankara. Aflatoxin M1 is found in 14 of the samples, the levels of which range from 10 to $400 \mathrm{ng} / \mathrm{kg}$. Aflatoxin M1 level of only one sample exceeds the maximum tolerable limit $(250 \mathrm{ng} / \mathrm{kg}$ ) according to the TFC, 2004. Bakırdere et al. (2014) report that $2.5 \%$ of kashar exceeds the TFC limit (2008) of $500 \mathrm{ng} / \mathrm{kg}$. AFM1 levels of half the samples range from 50 to $700 \mathrm{ng} / \mathrm{kg}$ with a mean of $130 \mathrm{ng} / \mathrm{kg}$. Despite the detectable levels of AFM1 in all cheese samples in this study, contamination levels are lower than those reported by Tekinsen \& Eken (2008), and Cetin (2004).

There are numerous studies on AFM1 content in milk products, however, the number of studies on AFM1 content in butter from Sakarya, Turkey is small. A study carried out by Fallah (2010) in Iran reports an incidence of AFM1 contamination in $25.8 \%$ of 31 butter samples, with AFM1 levels ranging from 13 to $26 \mathrm{ng} / \mathrm{kg}$ and a mean of $5 \mathrm{ng} / \mathrm{kg}$. AFM1 levels of $17(52 \%)$ of butter samples in the study conducted by Iqbal \& Asi (2013) 
exceed the EC limits. AFM1 levels range from 4 to $413 \mathrm{ng} / \mathrm{kg}$ with a mean of $156.29 \mathrm{ng} / \mathrm{kg}$. Var \& Kabak (2009) examined 70 dairy products, 10 of which are butter samples, from various supermarkets in Adana, Turkey. They report an incidence of AFM1 in 3 of 10 butter samples. Ayçiçek et al. (2005) analyze AFM1 occurrence in 27 butter samples from Ankara, Turkey. They report an AFM1 contamination rate of $90.58 \%$ in dairy products in general and of $92.6 \%$ in butter in particular. Tekinşen \& Uçar (2007) analyze 92 butter samples purchased at retail outlets in five big cities in Turkey for AFM1 contamination. They find that all butter samples are contaminated with AFM1, the levels of which range from 10 to $7.000 \mathrm{ng} / \mathrm{kg}$. Aydemir Atasever et al. (2010) detect AFM1 in 80 butter samples purchased from supermarkets in Erzurum, Turkey, suggesting AFM1 contamination in 66 (82.5\%) of the samples. AFM1 levels vary between 10 and $121 \mathrm{ng} / \mathrm{kg}$ with a mean of $30.4 \mathrm{ng} / \mathrm{kg}$. However, in this study, butter samples contain small quantities of AFM1, the levels of which range from 5.20 to $48.22 \mathrm{ng} / \mathrm{kg}$ with a mean of $15.71 \mathrm{ng} / \mathrm{kg}$, suggesting that AFM1 levels of butter samples from Sakarya do not exceed the recommended limits set by the TFC (Turkish Food Codex, 2011). However, AFM1 levels reported in the studies above are higher than those determined in this study. In the study conducted by Aksoy et al. (2016), 40 butter samples from the Black Sea region do not contain AFM1. Tosun \& Ayyildiz (2013) examined AFM1 levels in organic MDPs purchased in Turkey between February 2010 and February 2011. No AFM1 contamination was observed in the butter samples. The levels reported by Tosun \& Ayyildiz (2013) are lower than those reported in this study.

\section{Conclusion}

The results show that milk and dairy samples (milk, cheese and butter) are contaminated with AFM1. However, AFM1 levels in MDPs do not exceed the maximum limits set by the TFC. AFM1 contamination levels in MDPs are lower than reported by earlier studies, indicating that quality and safety of milk in Turkey have improved. One limitation of this study is the small sample size. It is recommended that more comprehensive and integrative studies be conducted for continuous monitoring of AFM1 levels in MDPs and that further surveillance programs for both feed and dairy products be carried out in order to be able to assess risks associated with AFM1. It is suggested that farmers and companies in the dairy industry in Sakarya, Turkey, pay attention to the potential health consequences of AFM1 and take measures to reduce AFM1 contamination and improve the quality of MDPs and protect public health.

\section{Acknowledgements}

This study was supported by Research Fund of Sakarya University (Project number: 201-01-16-011).

\section{References}

Abdolgader, R. E., Mohamed, S. E., Agoub, A. A., Bosallum, S. T., \& Hasan, S. M. (2017). A study the occurance of aflatoxin M1 in raw and sterilized milk in Eljabal Alakder region of Libya. International Journal of Science and Research Methodology Human, 5(3), 1-8.
Aksoy, A., Atmaca, E., Yazıcı, F., Güvenç, D., Gül, O., \& Dervisoglu, M. (2016). Comparative analysis of aflatoxin in marketed butter by ELISA and HPLC. Kafkas Üniversitesi Veteriner Fakültesi Dergisi, 22(4), 619-621.

Aksoy, A., Yavuz, O., Güvenc, D., Das, Y. K., Terzi, G., \& Celik, S. (2010). Determination of aflatoxin levels in raw milk, cheese and dehulled hazelnut samples consumed in samsun Province, Turkey. Kafkas Üniversitesi Veteriner Fakültesi Dergisi, 16(Suppl A), S513-S516.

Aliabadi, M. A., Issazadeh, K., Darsanaki, R. K., Rokhi, M. L., \& Amini, A. (2012). Determination of aflatoxin M1 levels in white cheese samples by ELISA in Gilan Province, Iran. Global Veterinaria, 8(7), 707-710.

Ardic, M. Y., Karakaya, M., Atasever, M., \& Adiguzel, G. (2009). Aflatoxin M1 levels of Turkish white brined cheese. Food Control, 20(3), 196-199. http://dx.doi.org/10.1016/j.foodcont.2008.04.003.

Ayar, A., Sert, D., \& Çon, A. H. (2007). A study on the occurrence of aflatoxin in raw milk due to feeds. Journal of Food Safety, 27(2), 199-207. http://dx.doi.org/10.1111/j.1745-4565.2007.00072.x.

Ayçiçek, H., Aksoy, A., \& Sayg1, S. (2005). Determination of aflatoxin levels in some dairy and food products which consumed in Ankara, Turkey. Food Control, 16(3), 263-266. http://dx.doi.org/10.1016/j. foodcont.2004.03.004.

Aydemir Atasever, M., Atasever, M., Özturan, K., \& Urçar, S. (2010). Determination of aflatoxin M1 level in butter samples consumed in Erzurum, Turkey. Kafkas Üniversitesi Veteriner Fakültesi Dergisi, 16(Suppl A), S159-S162.

Bahrami, Z., Shahbazi, Y., \& Nikousefat, Z. (2016). Aflatoxin $M_{1}$ in milk and traditional dairy products from west part of Iran: occurrence and seasonal variation with an emphasis on risk assessment of human exposure. Food Control, 62, 250-256. http://dx.doi.org/10.1016/j. foodcont.2015.10.039.

Bakırdere, S., Yaroğlu, T., Tırık, N., Demiröz, M., \& Karaca, A. (2014). Determination of trace aflatoxin M1 levels in milk and milk products consumed in Turkey by using enzyme-linked immunosorbent assay. Food and Agricultural Immunology, 25(1), 61-69. http://dx.doi.org/ 10.1080/09540105.2012.733354.

Beasley, V. R. (2011). Pathophysiology and clinical manifestations of mycotoxin and phycotoxin poisonings. Egyptian Journal of Natural Toxins, 8, 104-133.

Bilandžić, N., Tanković, S., Jelušić, V., Varenina, I., Solomun Kolanović, B., Luburić, Đ. B., \& Cvetnić, Ž. (2016). Aflatoxin M1 in raw and UHT cow milk collected Bosnia and Herzegovina Croatia. Food Control, 68, 352-357. http://dx.doi.org/10.1016/j.foodcont.2016.04.022.

Cetin, T. (2004). Determination of possible aflatoxin M1 presence by HPLC method in kasar cheeses marketted in Ankara (Master's thesis). Graduate School of Natural and Applied Sciences Department of Milk Technology, Ankara University, Ankara.

Colak, H., Hampikyan, H., Ulusoy, B., \& Ergun, O. (2006). Comparison of a competitive ELISA with an HPLC method for the determination of aflatoxin M1 in Turkish White, Kasar and Tulum cheeses. European Food Research and Technology, 223(6), 719-723. http:// dx.doi.org/10.1007/s00217-006-0258-4.

Deveci, O. (2007). Changes in the concentration of aflatoxin $M_{1}$ during manufacture and storage of White Pickled cheese. Food Control, 18(9), 1103-1107. http://dx.doi.org/10.1016/j.foodcont.2006.07.012.

Ellis, W., Smith, J., Simpson, B., Oldham, J., \& Scott, P. M. (1991). Aflatoxins in food: occurrence, biosynthesis, effects on organisms, detection, and methods of control. Critical Reviews in Food Science and Nutrition, 30(4), 403-439. http://dx.doi.org/10.1080/10408399109527551. PMid:1910523. 
Ertaş, N., Gonulalan, Z., Yildirim, Y., \& Karadal, F. (2011). A survey of concentration of aflatoxin M1 in dairy products marketed in Turkey. Food Control, 22(12), 1956-1959. http://dx.doi.org/10.1016/j. foodcont.2011.05.009.

European Union, European Commission. (2006). Commission regulation (EC) $n^{\circ} 1881 / 2006$ of 19 December 2006 setting maximum levels for certain contaminants in foodstuffs. Official Journal of the European Union, L364/5..

European Union, European Commission. (2010). Regulation n ${ }^{\circ}$ 165/2010 of 26 February 2010 setting maximum levels for certain contaminants in foodstuffs. Official Journal of the European Union, L50/8.

Fallah, A. A. (2010). Aflatoxin M1 contamination in dairy products marketed in Iran during winter and summer. Food Control, 21(11), 1478-1481. http://dx.doi.org/10.1016/j.foodcont.2010.04.017.

Fallah, A. A., Jafari, T., Fallah, A., \& Rahnama, M. (2009). Determination of aflatoxin M1 levels in Iranian white and cream cheese. Food and Chemical Toxicology, 47(8), 1872-1875. http://dx.doi.org/10.1016/j. fct.2009.04.042. PMid:19426778.

Farah Nadira, A., Rosita, J., Norhaizan, M. E., \& Mohd Redzwan, S. (2017). Screening of aflatoxin M1 occurrence in selected milk and dairy products in Terengganu, Malaysia. Food Control, 73, 209-214. http://dx.doi.org/10.1016/j.foodcont.2016.08.004.

Golge, O. (2014). A survey on the occurrence of aflatoxin $M_{1}$ in raw milk produced in Adana province of Turkey. Food Control, 45, 150155. http://dx.doi.org/10.1016/j.foodcont.2014.04.039.

Gul, O., \& Dervisoglu, M. (2014). Occurrence of Aflatoxin M1 in Vacuum Packed Kashar Cheeses in Turkey. International Journal of Food Properties, 17(2), 273-282. http://dx.doi.org/10.1080/109 42912.2011 .631247$.

Gurbay, A., Aydın, S., Girgin, G., Engin, A. B., \& Şahin, G. (2006). Assessment of aflatoxin M1 levels in milk in Ankara, Turkey. Food Control, 17(1), 1-4. http://dx.doi.org/10.1016/j.foodcont.2004.07.008.

Gurses, M., Erdoğan, A., \& Cetin, B. (2004). Occurrence of Aflatoxin M1 in some cheese types sold in Erzurum, Turkey. Turkish Journal of Veterinary and Animal Sciences, 28, 527-530.

International Agency for Research on Cancer - IARC. (2012). Monographs on the evaluation of carcinogenic risks to humans: chemical agents and related occupations (Vol. 100F, pp. 224-248). Lyon: International Agency for Research on Cancer.

Iqbal, S. Z., \& Asi, M. R. (2013). Assessment of aflatoxin M1 in milk and milk products from Punjab, Pakistan. Food Control, 30(1), 235-239. http://dx.doi.org/10.1016/j.foodcont.2012.06.026.

Joint FAO/WHO Expert Committee on Food Additives - JECFA. (2002). Evaluation of certain mycotoxins in food (WHO Technical Report Series, No. 896). Geneva: WHO.

Ketney, O., Santini, A., \& Oancea, S. (2017). Recent aflatoxin survey data in milk and milk product: a review. International Journal of Dairy Technology, 70(3), 1-12. http://dx.doi.org/10.1111/1471-0307.12382.

Koluaçık, A., Tirpancı Sivri, G., \& Kaptan, B. (2015). Aflatoxin M1 determination in traditional küp cheese samples of Turkey using immunoaffinity column and high-performance liquid chromatography. Turkish Journal of Agriculture-Food Science and Technology, 3(12), 916-919. http://dx.doi.org/10.24925/turjaf.v3i12.916-919.504.

Li, S., Min, L., Wang, P., Zhang, Y., Zheng, N., \& Wang, J. (2017). Occurrence of aflatoxin M1 in pasteurized and UHT milks in China in 2014-2015. Food Control, 78, 94-99. http://dx.doi.org/10.1016/j. foodcont.2017.02.042.
Mayes, L., \& McDonald, S. (1995). Aflatoxin M1 in retail milk and milk products (Report FD 94/98A). Colney Norwich: Central Science Laboratory.

Oliveira, C. P., Soares, N. F. F., Oliveira, T. V., Baffa, J. C. Jr., \& Silva, W. A. (2013). Aflatoxin M1 occurrence in ultra-high temperature (UHT) treated fluid milk from Minas Gerais/Brazil. Food Control, 30(1), 90-92. http://dx.doi.org/10.1016/j.foodcont.2012.07.026.

Oruç, H. H. (2003). Süt ve süt ürünlerinde aflatoksin M1 (AFM1) ve Türkiye'deki durumu. Uludag University Journal of Veterinary Medicine, 22, 121-125.

Ozdemir, C., \& Demirci, M. (2006). Selected microbiological properties of Kashar cheese samples preserved with potassium sorbate. International Journal of Food Properties, 9(3), 515-521. http://dx.doi. org/10.1080/10942910600596191.

Piva, G., Pietri, A., Galazzi, L., \& Curto, O. (1988). Aflatoxin M1 occurrence in dairy products marketed in Italy. Food Additives and Contaminants, 5(2), 133-139. http://dx.doi.org/10.1080/02652038809373692. PMid:3129321.

Prandini, A., Tansini, G., Sigolo, S., Filippi, L., Laporta, M., \& Piva, G. (2009). On the occurrence of aflatoxin M1 in milk and dairy products. Food and Chemical Toxicology, 47(5), 984-991. http:// dx.doi.org/10.1016/j.fct.2007.10.005. PMid:18037552.

Rama, A., Montesissa, C., Lucatello, L., Galina, G., Benetti, C., \& Bajraktari, D. (2016). A study on the occurance of aflatoxin in milk consumed in Kosovo during 2009-2010. Food Control, 62, 52-55. http://dx.doi.org/10.1016/j.foodcont.2015.10.019.

Sharifzadeh, A., Ghasemi-Dehkordi, P., Foroughi, M., MardanpourShahrekordi, E., \& Ramazi, S. (2017). Aflatoxin M1 in cheeses sold in Isfahan province, Iran. Osong Public Health and Research Perspectives, 8(4), 260-263. http://dx.doi.org/10.24171/j.phrp.2017.8.4.05. PMid:28904848.

Tekinsen, K. K., \& Eken, H. S. (2008). Aflatoxin M1 levels in UHT milk and Kashar cheese consumed in Turkey. Food and Chemical Toxicology, 46(10), 3287-3289. http://dx.doi.org/10.1016/j.fct.2008.07.014. PMid:18700163.

Tekinşen, K. K., \& Uçar, G. (2007). Aflatoxin M1 levels in butter and cream cheese consumed in Turkey. Food Control, 19(1), 27-30. http:// dx.doi.org/10.1016/j.foodcont.2007.01.003.

Tosun, H., \& Ayyildiz, T. (2013). Occurence of aflatoxin M1 in organic dairy products. Quality Assurance and Safety of Crops \& Foods, 5(3), 215-219. http://dx.doi.org/10.3920/QAS2012.0147.

Turkish Food Codex - TFC. (2011, December 29). Regulation no. $2011 / 28157$, the maximum allowed level of food contaminants. Official Gazette of Publication.

Var, I., \& Kabak, B. (2009). Detection of aflatoxin M1 in milk and dairy products consumed in Adana, Turkey. International Journal of Dairy Technology, 62(1), 15-18. http://dx.doi.org/10.1111/j.14710307.2008.00440.x.

Yoon, B. R., Hong, S. Y., Cho, S. M., Lee, K. R., Kim, M., \& Chung, S. H. (2016). Aflatoxin M1 levels in dairy products from South Korea determined by high performance liquid chromatography with fluorescens detection. Journal of Food and Nutrition Research, 55(2), 171-180.

Zheng, N., Sun, P., Wang, J., Zhen, Y., Han, R., \& Xu, X. (2013). Occurrence of aflatoxin M1 in UHT milk and pasteurized milk in China market. Food Control, 29(1), 198-201. http://dx.doi. org/10.1016/j.foodcont.2012.06.020. 